\title{
UPTAKE AND TRANSLOCATION OF SOME HEAVY METALS BY RICE CROP (ORYZA SATIVA) IN PADDY SOILS
}

\author{
GHASEM RAHIMI*, ZAHRA KOLAHCHI, AMIN CHARKHABI
}

College of Agriculture, Bu-Ali Sina University, Hamedan, Iran

RAHIMI, G. - KOLAHCHI, Z. - CHARKHABI, A.: Uptake and translocation of some heavy metals by rice crop (Oryza sativa) in paddy soils. Agriculture (Pol'nohospodárstvo), vol. 63, 2017, no. 4, pp. 16ロ-17ロ.

\begin{abstract}
Accumulation of heavy metals in edible crops is amongst major international concerns today. While consuming Lenjan variety of rice is very popular in Iran, limited evidence exists on its safety. Amid increasing public concern about the safety of locally grown and imported rice in the market, a field study was carried out to investigate uptake and translocation of $\mathrm{Cd}, \mathrm{Pb}$, $\mathrm{Ni}$, and $\mathrm{Zn}$ by a local variety of rice crop (Oryza sativa) exposed to contaminated water. At harvest time and in paddy fields, 41 soil and plant samples were collected from four locations of Lenjan, central Iran; irrigated from Zayandeh Rood River. In the laboratory, different parts of the plant were milled, digested via acid digestion method, and then analysed for $\mathrm{Cd}, \mathrm{Pb}$, $\mathrm{Ni}$ and $\mathrm{Zn}$ using atomic absorption spectrophotometry. The results showed that average concentrations of $\mathrm{Cd}, \mathrm{Pb}, \mathrm{Ni}$ and $\mathrm{Zn}$ were $1.07,17.22,1.73$ and $13.75 \mathrm{mg} / \mathrm{kg}$ in the plant's stem; and $1.27,12.32,1.099$ and $19.39 \mathrm{mg} / \mathrm{kg}$ in its grain, respectively. In general, both in the plant's stem and grain, the $\mathrm{Cd}$ and $\mathrm{Pb}$ concentrations were much higher than the FAO/WHO standard and labelled as harmful for consumers. Moreover, among the studied heavy metals, Ni transported very weakly, while Cd and $\mathrm{Zn}$ conveyed most easily into the plant's stem and grain. Of course, $\mathrm{Pb}$ was the least mobile metal. However, it had highly accumulated in the plant's stem and grain.
\end{abstract}

Key words: heavy metal $\square$ rice plant $\square$ translocation factor $\square$ paddy soils $\square$ paddy crop $\square$ Oryza sativa

\section{INTRODUCTION}

Agricultural soil and water contamination has become a severe environmental problem in many developed and developing countries in recent years (Facchinelli et al. 2001; Kalavrouziotis et al. 2012; Fan et al. 2017). Heavy metals, one of such toxic contaminants, are not bio- and thermo-degradable, hence accumulate in the environment up to hazardous levels (Chung et al. 2011). Two primary sources of heavy metals in the soil are: (i) the natural background -i.e. metals derived from parent rocks; and (ii) the anthropogenic contamination -i.e. those originated from human activities (Fu et al. 2008; Zhao et al. 2010). Most of the soil metals today have originated from anthropogenic sources than natural ones (Moura et al. 2010). Meanwhile, irrigation of agricultural soil with polluted municipal and industrial wastewater is another vital source of pollution (Mahmoud \& Ghoneim 2016).

The soil-to-plant transfer of heavy metals is a process of significant importance (Kalavrouziotis et al. 2012). In plants, heavy metals might cause oxidative stress, displace essential metals, disrupt metabolic processes from functioning, and finally reduce yield (Wang-da et al. 2006). Furthermore, chronic low-level intake of heavy metals can pose an irreversible detrimental effect on human health

Rahimi Ghasem, Associate Professor (*Corresponding author), Department of Soil Science, College of Agriculture, Bu-Ali Sina University, Hamedan, Iran. E-mail: g.rahimi@basu.ac.ir

Kolahchi Zahra, Assisstant Professor, Department of Soil Science, College of Agriculture, Bu Ali Sina University, Hamedan, Iran. E-mail: zkolahchi@basu.ac.ir

Charkhabi Amin, Postgraduate Student, Department of Soil Science, College of Agriculture, Bu Ali Sina University, Hamedan, Iran. E-mail: amin_charkhabi@yahoo.com 
(Rattan et al. 2005; Rodriguez Martin et al. 2006; Hang et al. 2009; Yang et al. 2009; Wu \& Zhang 2010). Among agricultural products, rice is widely consumed as a staple food worldwide and especially in Asian countries. So, in case of contamination, it could become a significant dietary source of toxic elements compared to other crops (Park et al. 2011; Tariq \& Rashid 2013). Therefore, its quality can profoundly affect human health. That is why heavy metals contamination in agricultural soils and their transfer into plants have been of increasing concern (Zhao et al. 2010).

Rice as a herbal plant contains protein and is ranked as the second highly consumed cereal in the world. Half of the world populations consume rice as their staple food (Rabbani et al. 2015). Some researchers showed a gradual increase of some heavy metals such as cadmium in Iranian rice and mentioned the situation as posing a significant threat (Zazoli et al. 2006).

The metal transfer factor (TF) is an indicator of heavy metal accumulation in plants. It quantifies the differences in the bioavailability of metal to plant. In other words, TF is an indicator of heavy metal mobility in the soil. Meanwhile, it is considered a critical parameter regarding the accumulation of heavy metals in plants. Of course, factors that contribute to the increase of heavy metal concentration in soil could have an impact on it, namely sludge application or wastewater reuse (Kalavrouziotis et al. 2012).

In recent years, researchers have focused their attention on the significance of soil types and genotype, and their impact on the uptake and accumulation of heavy metals in potted experiments (Chung et al. 2011; Lai et al. 2012). However, the pot experiments may not be able to predict uptake of heavy metals by a crop under actual field conditions. Accordingly, it is crucial to study heavy metals accumulation in plants' natural environment. Multiple metals' pollution of agricultural soils is turned into a common phenomenon, regarding human activities. It is believed that interactions of such different elements create a different toxic effect on an ecosystem compared to that of single pollutant (Liu et al. 2007). Therefore, in the present research, we performed a comprehensive study of toxic heavy metals in rice plants and their agricultural soils under natural conditions from renowned Lenjan paddy fields of central Iran.

\section{MATERIAL AND METHODS}

\subsection{Study area}

The area selected for present study is located in Lenjan, southwest Isfahan Province, central Iran; with a semi-arid climate, and an average annual temperature and rainfall of $15.7^{\circ} \mathrm{C}$ and $157.7 \mathrm{~mm}$, respectively (Iran Meteorological Organization 2017). Many active industrial units were placed adjacent to the study area. The growing period of rice plant (Oryza sativa) was about 155 days (May- October) in the Lenjan Region. Traditionally, rice is broadly cultivated in the area, with a great yield annually. However, most of the produced rice is consumed by residents. According to the local records, large amounts of chemical fertilisers, pesticides, and manures have been being applied to above-mentioned paddy fields over a long period. Surrounding industrial activities and urbanisation could have also affected the soil environment.

\subsection{Sampling}

Out of the greatest sources of pollution in the region, samples were collected from 41 sites in 2014. Researchers divided them into four districts, namely: 1-Zarrinshahr: an industrial and municipal sewage and river irrigation region, 2-Sede: a river and municipal sewage irrigation region, 3-Chamgordan: an industrial and municipal sewage irrigation region, and 4-Varnamkhast: a municipal sewage irrigation region. All collected samples were stored in polyethylene bags and brought to the soil science laboratory of Bu Ali Sina University, Iran for further preparation and treatment.

\subsubsection{Soil sampling}

Soil samples were collected from the fields' $0-20$ $\mathrm{cm}$ soil layer. At first, they were air-dried at room temperature, then finely powdered, homogenised, and grinded to pass through a 2-mm nylon sieve. Later the samples were analysed for some of their physical and chemical properties. The $\mathrm{pH}$ (at the ratio of 1:5 soil-distilled water), EC (at the ratio of 1:5 soil-distilled water), calcium carbonate equivalent, soil texture, and soil organic matter plus cation ex- 
change capacity were identified according to Thomas (1996), Sims (1996), Bauycos (1962), and Rowell (1994) guidelines; respectively. Total and available concentrations of heavy metals were measured by the method of Sposito et al. (1982) and Lindsay and Norvell (1978).

\subsubsection{Water sampling}

Water samples were collected from 2 sites (The Zayandeh Rood river and municipal wastewater). They were preserved in 1-L polypropylene sampling bottles at $4^{\circ} \mathrm{C}$ in darkness and analysed within $48 \mathrm{~h}$ (Hai et al. 2009).

\subsubsection{Plant sampling}

The plants' samples were taken in their maturity from approximately very same locations where the soils were sampled and simultaneously for further studies on the heavy metals mobility and bioavailability. In the laboratory, sampled rice plants were separated into their different parts such as roots, stems and grains; Then, they were washed three times with distilled water, rinsed with deionised water, and finally dried in an oven at $65^{\circ} \mathrm{C}$. Later, the samples' dry weights were determined, and afterwards, the plant parts grinded with a tissue grinder (Liu et al. 2007). Samples digested with $8 \mathrm{~mL}$ of $70 \% \mathrm{HNO}_{3}$, then cooling to room temperature, were filtered through a $0.45-\mu \mathrm{m}$ membrane filter, and adjusted to a final volume of $25 \mathrm{ml}$ (Park et al. 2011). At last, some metal concentrations including $(\mathrm{Cd}$, $\mathrm{Pb}, \mathrm{Ni}$ and $\mathrm{Zn}$ ), in three parts of the plant comprising (roots, stems and seeds) were determined using atomic absorption spectrophotometry.

\subsection{Bio-accumulation factor}

The bio-accumulation factor (BAF) is defined as the ratio of an element's concentration in plant's grain to that element's concentration in the corresponding soil. BAF was calculated for each plant sample to quantify the plant's bio-accumulation effect, up-taking heavy metals from the soils (Hang et al. 2009). The BAF was computed with the following formulae (eq. 1):

$\mathrm{BAF}=\frac{\mathrm{Cr}}{\mathrm{Cs}} \quad$ eq. 1 ,

where $\mathrm{Cr}$ and $\mathrm{Cs}$ represented the heavy metals'

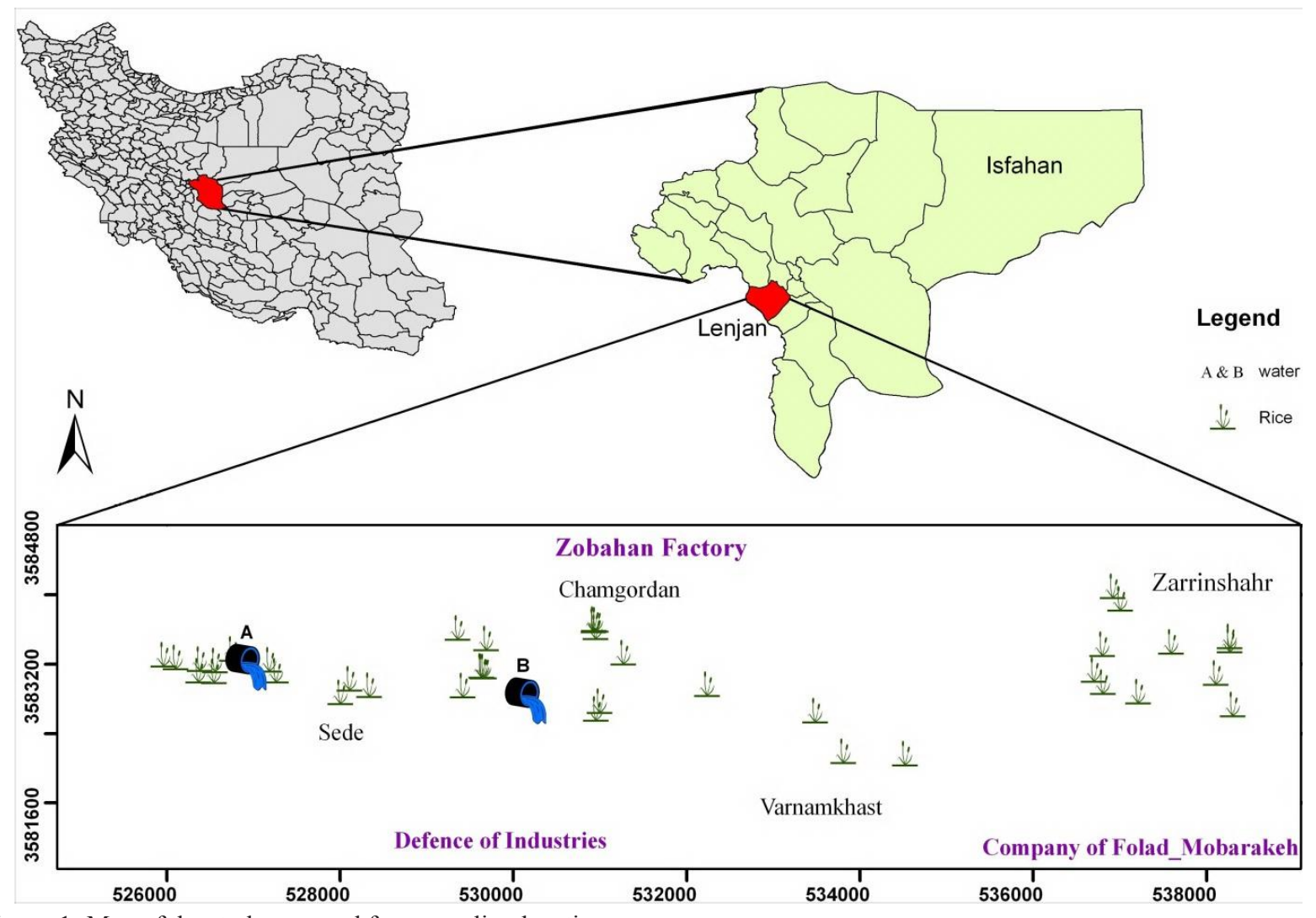

Figure 1. Map of the study area and four sampling locations 
concentrations in the grain and soils extracts; respectively, on a dry weight basis (Hang et al. 2009; Singh et al. 2011).

\subsection{Transfer of heavy metals from the soils to the} rice plants

Concentrations of heavy metals in rice plant vary depending on total metal concentrations in their paddy soils (Jung \& Thornton 1997). Therefore, the transfer factor (TF) of the heavy metals were calculated by dividing the concentration of every metal in the plant over its total concentration in the soil. Higher TFs reflect relatively poor retention in soil or greater efficiency of the plant to absorb metal; while lower TFs indicate strong sorption of metal to the soil colloid (Zhen et al. 2009).

Moreover, the translocation factor is calculated as the ratio of metal concentration in aerial parts of any plant over that metal's concentration in the plant root. In other words, $\mathrm{TF}=\left(\mathrm{C}_{\text {aerial }} / \mathrm{C}_{\text {root }}\right)$, where, $\mathrm{C}_{\text {aerial }}$ is the metal concentration in plant's aerial part, and $\mathrm{C}_{\text {root }}$ is that metal concentration in the plant's root (Tiwari et al. 2011; Singh et al. 2011).

\section{RESULTS AND DISCUSSION}

\subsection{Physico-chemical parameters of the soil}

As shown in Table 1, the main physicochemical parameters determined for topsoil's from the study area were as the followings: (i) The OM contents were within the range of $0.76-4.14 \%$, (ii) values of $\mathrm{pH}$ fell in a narrow range (7.02-8.24), indicating sub-alkaline conditions for all the sampled topsoils; (iii) values of CEC showed high variation (10.1$47.56 \mathrm{cmol} / \mathrm{kg}$ ) with a mean value of $20.81 \mathrm{cmol} / \mathrm{kg}$. (IV) The $\mathrm{CaCO}_{3}$ content ranged from 17.91 to
36.83; (V) the electrical conductivity ranged from 0.152-3.266 dS/m. Also, the contents of clay, silt and sand varied between 16-31, 16-48 and 27-57 percentages, respectively.

\subsection{Soil contamination}

Total and available heavy metal concentrations in the soils are presented in Table 2. Total and available concentrations of $\mathrm{Cd}$ and $\mathrm{Pb}$, measured in the soils exceeded those in arable soils not subject to gross anthropogenic pollution, reported by Bi et al. (2010) that ranged between $0.1-2 \mathrm{mg} / \mathrm{kg}$ and $20-50 \mathrm{mg} / \mathrm{kg}$; respectively.

The maximum allowable concentration of $\mathrm{Ni}$ in agricultural soils was proposed to be $50 \mathrm{mg} / \mathrm{kg}$ (Kabata Pendias 2010). However, in the present study, the mean concentration of $\mathrm{Ni}$, obtained from all the sampled regions, was higher than what considered safe for agricultural soils.

The threshold of $\mathrm{Zn}$ is defined at $60 \mathrm{mg} / \mathrm{kg}$ in the topsoil (Sposito 1989; Manata \& Angelone 2002; Kabata Pendias 2010). In comparison with the above standard, in approximately $50 \%$ of the samples, the $\mathrm{Zn}$ concentrations were higher than the standard, emphasising on anthropogenic sources of the contaminant which might be due to irrigating the rice crops with industrial and municipal wastewater. Tiwari et al. (2011) found that agricultural soils which repeatedly irrigated with industrial effluent were contaminated with $\mathrm{Pb}, \mathrm{Cd}, \mathrm{Cu}, \mathrm{Fe}, \mathrm{Mn}, \mathrm{Ni}$ and $\mathrm{Zn}$.

The DTPA extracted-metal contents, which are commonly recognised as available for uptake by plants, also differed among the soils. Among the four heavy metals in the study, $\mathrm{Zn}$ showed the most substantial relative difference, presented as the ratio of the maximum/minimum concentration, which was

$\mathrm{T}$ a

Some soil properties in the study area

\begin{tabular}{|l|c|c|c|c|c|c|c|c|}
\hline & $\begin{array}{c}\mathrm{CaCO}_{3} \\
{[\%]}\end{array}$ & $\mathrm{pH}$ & $\begin{array}{c}\mathrm{EC} \\
{[\mathrm{dS} / \mathrm{m}]}\end{array}$ & $\begin{array}{c}\mathrm{CEC} \\
{[\mathrm{cmol} / \mathrm{kg}]}\end{array}$ & $\begin{array}{c}\mathrm{OM} \\
{[\%]}\end{array}$ & $\begin{array}{c}\text { Clay } \\
{[\%]}\end{array}$ & $\begin{array}{c}\text { Silt } \\
{[\%]}\end{array}$ & $\begin{array}{c}\text { Sand } \\
{[\%]}\end{array}$ \\
\hline Min & 17.91 & 7.02 & 0.152 & 10.10 & 0.76 & 16.00 & 16.00 & 27.00 \\
Max & 36.83 & 8.24 & 3.266 & 47.56 & 4.14 & 31.00 & 48.00 & 57.00 \\
Mean & 24.80 & 7.68 & 0.487 & 20.81 & 2.49 & 23.28 & 33.43 & 43.27 \\
\hline
\end{tabular}


$1.51 \mathrm{~Pb}$ ranked the second with a relative difference of 1.28 among the locations. Meanwhile, the other two elements had smaller differences, -i.e. 1.21 and 1.14 for the $\mathrm{Cd}$ and $\mathrm{Ni}$, respectively. It could be due to different levels of contamination.

\subsection{Chemical properties and metal concentrations of the water samples}

The mean values for chemical properties and heavy metal concentrations -i.e. $\mathrm{Cd}, \mathrm{Pb}, \mathrm{Ni}$ and $\mathrm{Zn}$, in the sampled water from a local river and municipal wastewater are shown in Table 3 . The $\mathrm{pH}$ of river water samples ranged from 8.04 to 8.31 ; while those of sampled municipal wastewater varied between 7.27 to 7.38 in the study area. The electrical conductivities of the wastewater samples were higher perhaps due to concentrated salts previously reported in municipal wastewater (Kiziloglu et al. 2008). According to the Table $3, \mathrm{Cd}, \mathrm{Pb}$ and $\mathrm{Zn}$ con- centrations in river water and municipal wastewater, commonly utilised for irrigation, were below the standard. Nevertheless, Ni concentrations in both groups of sampled water exceeded the pollution standards. The higher concentration of $\mathrm{Cd}, \mathrm{Pb}$ and $\mathrm{Zn}$ in the river, compared to municipal wastewater, can be attributed to the later discharge of industrial pollutants into the river. Of course, depending on the type of industrial activity, discharged waste into the water resources may contain different heavy metals. Continued use of such polluted water would lead to accumulation of heavy metals in soil and plant (Singh et al. 2010; Mahmoud \& Ghoneim 2016).

\subsection{Tracing the elements' concentrations in rice plant's parts}

\section{$3.4 .1 \mathrm{Cd}$}

The range and mean concentrations of $\mathrm{Cd}, \mathrm{Pb}$, $\mathrm{Ni}$ and $\mathrm{Zn}$ in various parts of the plants cultivated

T

Concentrations $[\mathrm{mg} / \mathrm{kg}]$ of total and available heavy metal in the soils

\begin{tabular}{|l|c|c|c|c|c|c|}
\hline Elements & Zarrinshahr & Sede & Varnamkhast & Chamgordan & aggregate & MAC* $^{*}$ \\
\hline Cd-Total & 1.320 & 2.360 & 0.628 & 1.051 & 1.700 & $0.1-2^{\mathrm{a}}$ \\
Cd-DTPA-extractable & 0.067 & 0.078 & 0.076 & 0.064 & 0.073 & - \\
Pb-Total & 48.700 & 44.600 & 80.230 & 71.010 & 53.540 & $20-50^{\mathrm{a}}$ \\
Pb-DTPA-extractable & 3.140 & 3.126 & 2.520 & 2.440 & 2.956 & - \\
Ni-Total & 63.920 & 54.710 & 55.410 & 52.920 & 52.460 & $50^{\mathrm{b}}$ \\
Ni-DTPA-extractable & 2.270 & 2.195 & 2.170 & 1.980 & 2.177 & - \\
Zn-Total & 95.436 & 63.032 & 51.755 & 50.352 & 66.648 & $60^{\mathrm{c}}$ \\
Zn-DTPA-extractable & 8.065 & 7.061 & 5.410 & 7.317 & 7.129 & - \\
\hline
\end{tabular}

*: maximum allowable concentrations (MAC)

a: Bi et al. (2010)

b: Kabata Pendias (2010)

c: Sposito (1989); Kabata Pendias (2010); Manata and Angelone (2002)

$\mathrm{T}$ a

Some chemical properties and heavy metals' concentration in the sampled river and municipal wastewater

\begin{tabular}{|l|c|c|c|c|c|c|}
\hline & $\mathrm{pH}$ & $\mathrm{EC}$ & $\mathrm{Cd}$ & $\mathrm{Pb}$ & $\mathrm{Ni}$ & $\mathrm{Zn}$ \\
\hline Zayandeh Rood River & 8.3 & 0.276 & 0.005 & 0.14 & 0.481 & 0.150 \\
Municipal Wastewater & 7.3 & 0.820 & 0.002 & 0.05 & 0.507 & 0.033 \\
MAC $^{\mathrm{a}}$ & - & - & 0.020 & 5.00 & 0.200 & 2.000 \\
MAC $^{\text {b }}$ & - & - & 0.010 & - & - & 5.000 \\
\hline
\end{tabular}

MAC: maximum allowable concentrations for irrigation purposes, Ayers and Westcott (1985)

$\mathrm{MAC}^{\mathrm{b}}$ : maximum allowable concentrations for irrigation purposes, Montgomery (1985) 
on paddy soils from four different areas of Lenjan, Iran are presented in Table 4. The mean value of $\mathrm{Cd}$ concentration in roots, stems and seeds of rice from different regions were $1.57,1.07$ and $1.27 \mathrm{mg} / \mathrm{kg}$ on dry weight basis, respectively. Fakoor Janati et al. (2011) studying 100 samples of rice purchased from some supermarkets in Iran, discovered $21 \mathrm{ng} / \mathrm{g}$ as the maximum content of $\mathrm{Cd}$ in rice. Zazoli et al. (2006) found that mean Cd concentration in Tarom rice (another variety of Iranian rice) was $0.41 \pm 0.17$ $\mathrm{mg} / \mathrm{kg}$ on dry weight basis. The allowable amount of $\mathrm{Cd}$ in plants (as shown in Table 5) has been reported to be $0.01-0.3 \mathrm{mg} / \mathrm{kg}$ dry weight (Alloway 1968). Moreover, the healthy food standard of $\mathrm{Cd}$ in rice, set by FAO/WHO codex (1984), was $0.3 \mathrm{mg} / \mathrm{kg}$ dry weight. Therefore, the average content of $\mathrm{Cd}$ in stems and grains of the sampled rice were 3.5 and 4.2 times more than the permissible limit, respectively. Findings revealed that amounts of $\mathrm{Cd}$ in all samples were above $0.3 \mathrm{mg} / \mathrm{kg}$ level. Also, Table 4 shows that concentrations of $\mathrm{Cd}$ in the plant's grains were higher than its stems. It was consistent with evidence that proved $\mathrm{Cd}$ possessed high mobility and easy absorption properties in plants, and could be easily absorbed by plants' root and skin, and then enter its tissues (Kabata Pendias 2010). With no proven beneficial effects on plants and animals; $\mathrm{Cd}$ proved to be toxic to plants, by reducing their photosynthesis, and water/nutrients uptake (Singh et al. 2011). It confirmed findings by Casado et al. (2008) that showed high Cd concentration in grasses induced by polluted soils.

The highest amount of $\mathrm{Cd}$, in different parts of the plant, was seen in the Sede region. However, ANOVA analysis revealed that there wasn't a significant difference $(P<0.05)$ in $\mathrm{Cd}$ contents of the rice plant from the four different regions (Table 4).

Results from previous studies (Khan et al. 2008) demonstrated that plants grown on wastewaterirrigated soils contaminated with heavy metals could pose a significant health risk to humans. Opposite to current study, Liu et al. (2007) stated that amounts of $\mathrm{Cd}$ in rice grains irrigated with municipal wastewater, river, and ground-water were 0.016, 0.038 and $0.0079 \mathrm{mg} / \mathrm{kg}$; respectively.

\subsection{2 $\mathrm{Pb}$}

Among the four regions, the highest, but not

T a b 1 e 4

Concentrations of heavy metals in various parts of the rice plants [mg/ $/ \mathrm{kg} \mathrm{dw}]$

\begin{tabular}{|c|c|c|c|c|c|c|c|c|c|}
\hline & \multicolumn{2}{|c|}{$\begin{array}{l}\text { Zarrinshahr } \\
\qquad(\mathrm{n}=11)\end{array}$} & \multicolumn{2}{|c|}{$\begin{array}{c}\text { Sede } \\
(\mathrm{n}=21)\end{array}$} & \multicolumn{2}{|c|}{$\begin{array}{l}\text { Chamgordan } \\
(\mathrm{n}=5)\end{array}$} & \multicolumn{2}{|c|}{$\begin{array}{l}\text { Varnamkhast } \\
\qquad(\mathrm{n}=4)\end{array}$} & \multirow{2}{*}{$\begin{array}{c}\begin{array}{c}\text { Total } \\
(\mathrm{n}=41)\end{array} \\
\text { Mean }\end{array}$} \\
\hline & Range & Mean & Range & Mean & Range & Mean & Range & Mean & \\
\hline \multicolumn{10}{|c|}{$\mathrm{Cd}$} \\
\hline Root & $1.20-1.75$ & 1.58 & $1.05-2.15$ & 1.60 & $1.20-1.75$ & 1.41 & $1.35-1.80$ & 1.56 & 1.57 \\
\hline Stem & $0.75-1.15$ & 0.92 & $0.50-5.45$ & 1.20 & $0.80-1.10$ & 0.92 & $0.80-1.50$ & 1.05 & 1.07 \\
\hline Grain & $1.02-1.60$ & 1.27 & $1.05-2.05$ & 1.28 & $1.25-1.40$ & 1.32 & $1.10-1.25$ & 1.18 & 1.27 \\
\hline \multicolumn{10}{|c|}{$\mathrm{Pb}$} \\
\hline Root & $22.5-42.5$ & 29.34 & $24.0-34.0$ & 27.82 & $25.50-28.00$ & 26.30 & $23.0-30.0$ & 26.37 & 27.90 \\
\hline Stem & $11.0-28.0$ & 18.72 & $9.5-24.0$ & 16.35 & $11.33-21.50$ & 18.23 & $11.5-23.5$ & 16.37 & 17.22 \\
\hline Grain & $11.0-15.3$ & 12.65 & $10.2-14.2$ & 12.36 & $11.00-12.75$ & 11.70 & $24.5-28.5$ & 11.94 & 12.32 \\
\hline \multicolumn{10}{|c|}{$\mathrm{Ni}$} \\
\hline Root & $5.85-18.7$ & 11.80 & $2.7-17.05$ & 9.98 & $5.5-16.2$ & 11.35 & $7.15-15.20$ & 11.20 & 10.75 \\
\hline Stem & $1.52-2.85$ & 2.13 & $0.5-2.60$ & 1.50 & $1.4-2.1$ & 1.78 & $1.13-3.06$ & 1.75 & 1.73 \\
\hline Grain & $0.10-2.50$ & 1.19 & $0.2-3.00$ & 1.07 & $0.1-2.3$ & 1.10 & $0.45-1.50$ & 0.95 & 1.099 \\
\hline \multicolumn{10}{|c|}{$\mathrm{Zn}$} \\
\hline Root & $19.60-56.3$ & 29.27 & $12.6-50.3$ & 23.83 & $9.24-33.70$ & 23.48 & $13.60-37.40$ & 28.57 & 25.71 \\
\hline Stem & $6.13-36.2$ & 16.20 & $0.23-37.9$ & 12.70 & $4.00-19.31$ & 11.77 & $6.30-25.39$ & 14.96 & 13.75 \\
\hline Grain & $16.20-33.6$ & 24.26 & $5.08-35.0$ & 18.75 & $8.25-17.30$ & 14.17 & $8.02-24.50$ & 15.84 & 19.39 \\
\hline
\end{tabular}


significant, concentration of $\mathrm{Pb}$ in the roots, stems and seeds of the plant were seen in Zarrinshahr as shown in Table 4. While FAO (1984) recommended $5 \mathrm{mg} / \mathrm{kg}$ as the safe limit of $\mathrm{Pb}$ uptake concentration for plants, Alloway (1968) and Kabata Pendias (2010) reported $3 \mathrm{mg} / \mathrm{kg}$ as the tolerable limit of $\mathrm{Pb}$ for upper parts of the plants. Meanwhile, Hang et al. (2009) introduced the $0.2 \mathrm{mg} / \mathrm{kg}$ as the $\mathrm{Pb}$ limit. Comparatively studying, $\mathrm{Pb}$ concentrations in the studied rice plants were much higher than the standard limit. Jahed Khaniki and Zazoli (2005) also found higher than the FAO/WHO guidelines' $\mathrm{Pb}$ content in the rice plants from northern Iran.

While $\mathrm{Pb}$ may easily be absorbed by plant roots and stems, only a small proportion of it moves into the aerial parts of the plants (Pais \& Jones 1997; Agarval 2002). In general, it is less mobile in the rice plants (Liu et al. 2007). Moreover, no significant correlations were observed between $\mathrm{Pb}$ concentrations in the sampled soils and aerial parts of the plant in the study (Table 6). Fu et al. (2008), in their study regarding heavy metal pollution in the rice crop, obtained a low correlation between soil and high levels of heavy metals in rice grains representing atmospheric deposition as a significant po- tential source of metals contamination of rice grains. Therefore, it seems to us that in the present study, an external factor such as atmospheric deposition could be blamed for $\mathrm{Pb}$ accumulation in aerial parts of the studied rice plants.

Anthropogenic entry and accumulation of $\mathrm{Pb}$ in the human food chain initiated from cultivated crops (Sillanppa \& Jansson 1992; Pais \& Jones 1997). Hang et al. (2009) in a risk assessment of contaminants in soil and rice from Changshu City, China discovered that concentrations of some heavy metals such as $\mathrm{Pb}$ in the plant could be related to substantial industrial activities in the region.

\section{$3.4 .3 \mathrm{Ni}$}

$\mathrm{Ni}$ concentrations in the rice grains were less than other parts of studied plans in paddy fields from various regions. The maximum concentrations of $\mathrm{Ni}$ in the roots, stems and seeds of the plant were found in Zarrinshahr, again. Not a substantial difference was revealed among the regions (Table 4). The Ni content in the plant roots was higher than other plant parts, and the Standard of China (2005). In the present study, Ni concentrations in sampled waters from the Zayandeh Rood river and municipal wastewater had reached the critical level (Table 3 ). It could play

T a b

Maximum levels of contaminants in plant tissues quoted from various sources

\begin{tabular}{|l|c|c|c|c|}
\hline Reference & $\mathrm{Cd}$ & $\mathrm{Ni}$ & $\mathrm{Zn}$ & $\mathrm{Pb}$ \\
\hline FAO and WHO (1984) & 0.3 & 20 & 60 & 5 \\
SEPA (2005)* & 0.2 & 10 & 100 & 9 \\
Doberman and Fairhurst (2000) & - & - & $20^{\mathrm{a}}, 40^{\mathrm{b}}$ & - \\
Alloway (1968) & 0.3 & - & 100 & 3 \\
Hang et al. (2009)** & 0.2 & & 50 & 0.2 \\
\hline
\end{tabular}

*: State Environmental Protection Administration, China

**: Maximum levels of contaminants in foods

$\mathrm{a}$ and b: Maximum levels of $\mathrm{Zn}$ in grain and stem, respectively, Doberman and Fairhurst (2000)

$\mathrm{T}$ a

Pearson correlation coefficients between $\mathrm{Cd}, \mathrm{Pb}, \mathrm{Ni}$ and $\mathrm{Zn}$ concentrations in soils and the plant parts

\begin{tabular}{|l|c|c|c|c|}
\hline Parts of the plant & $\mathrm{Cd}$ & $\mathrm{Pb}$ & $\mathrm{Zn}$ & $\mathrm{Ni}$ \\
\hline Root & $0.322^{*}$ & -0.134 & $0.316^{*}$ & $0.353^{*}$ \\
Stem & 0.080 & 0.020 & 0.199 & 0.190 \\
Grain & 0.030 & -0.220 & 0.080 & 0.240 \\
\hline
\end{tabular}

*significant difference at $p<0.05$ by the Duncan test 
a significant role in the consequent contamination of local soil and plants. Rattan et al. (2005) by investigating the impact of municipal effluent on the amount of $\mathrm{Ni}$ in cereals, illustrated that $\mathrm{Ni}$ uptake was dependent on its concentration in irrigation water.

\subsubsection{Zn}

The average $\mathrm{Zn}$ concentration in the stems was less than that of the roots and grains of the paddy crop across various regions. The maximum allowable concentration of zinc in plants varies in different sources. FAO and WHO (1984) reported the normal concentration of $\mathrm{Zn}$ in plants to be $60 \mathrm{mg} / \mathrm{kg}$ dry weight; whereas, Hang et al. (2009), SEPA (2005) and Alloway (1968) proposed $100 \mathrm{mg} / \mathrm{kg}$ as the permissible limit (Table 5). According to the proposed limits, the $\mathrm{Zn}$ contents in the stems and grains of the plant stood within the normal range. Of course, the $\mathrm{Zn}$ concentration in the rice roots cultivated in Zarrinshahr region was higher than expected, and exceeded the FAO (1984) standards.

Zarrinshahr had the highest total and available concentration of $\mathrm{Zn}$ in soils, as well (Table 2). Releasing industrial and municipal wastewater into water resources could have led to increasing con- centrations of $\mathrm{Zn}$ in the soil and plants of the study area. Abbas et al. (2007) in a study on the effects of contaminated water of Nullah Dek on rice paddy saw elements accumulation in different parts of rice plant and soil. Moreover, they delineated that concentrations of all trace elements including $(\mathrm{Zn}, \mathrm{Cu}$, $\mathrm{Fe}$ and $\mathrm{Mn}$ ) were increased by applying the Nullah Dek water which was already contaminated with industrial effluents carrying different micronutrients.

\subsection{Translocation of metals from soil into the rice} plants

\subsubsection{Bio-accumulation factor}

Figure 2 shows the bio-accumulation factors (BAF) calculated for heavy metal transfer from soils to the rice grain. The BAFs for heavy metals across studied regions in a descending order were as the following: $\mathrm{Cd}$ (Varnamkhast $>$ Zarrinshahr $>$ Chamgordan $>$ Sede, with a significant difference in TF values among different regions), Ni (Chamgordan $>$ Zarrinshahr $>$ Sede $>$ Varnamkhast, with no significant difference in TF values among different regions), $\mathrm{Pb}$ (Sede $>$ Zarrinshahr $>$ Varnamkhast $>$ Chamgordan, with a significant difference in TF values among different regions), and Zn (Varnam-

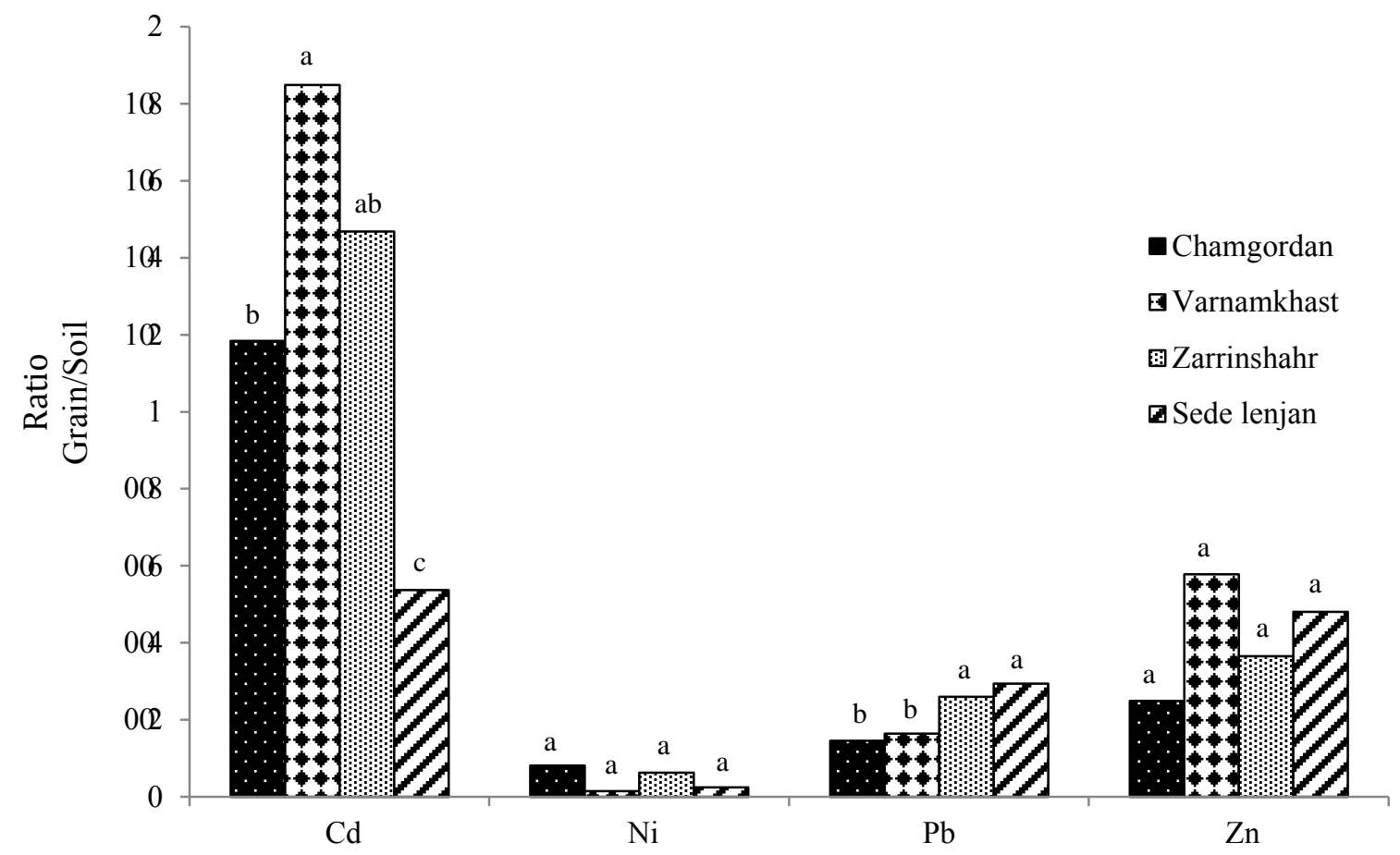

Figure 2. BAFs of the metals in the study area 
khast $>$ Sede $>$ Zarrinshahr $>$ Chamgordan, with no significant difference in TF values among different regions).

Principally, the food chain (soil-plant-human) is recognised as the major pathway for human expo- sure to soil contamination. The soil-to-plant transfer is one of the key components of human exposure to metals through the food chain. When $\mathrm{BCF}<1$ or $\mathrm{BAF}=1$, this denotes that the plant only absorbs but do not accumulate heavy metals; when $\mathrm{BCF}>1$,

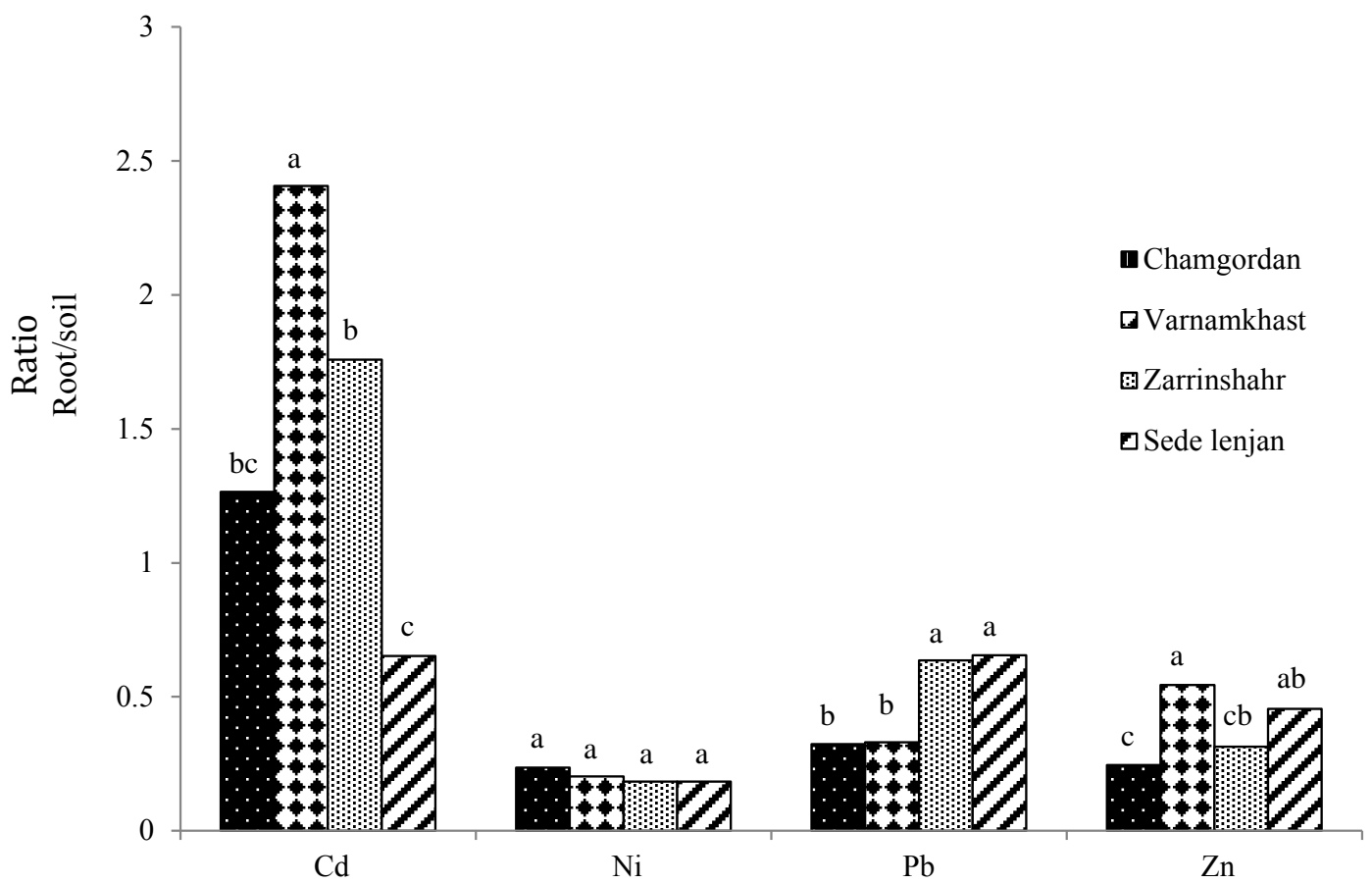

Figure 3. Metal transfer factor from soil to roots of rice (same letters indicate no significant difference)

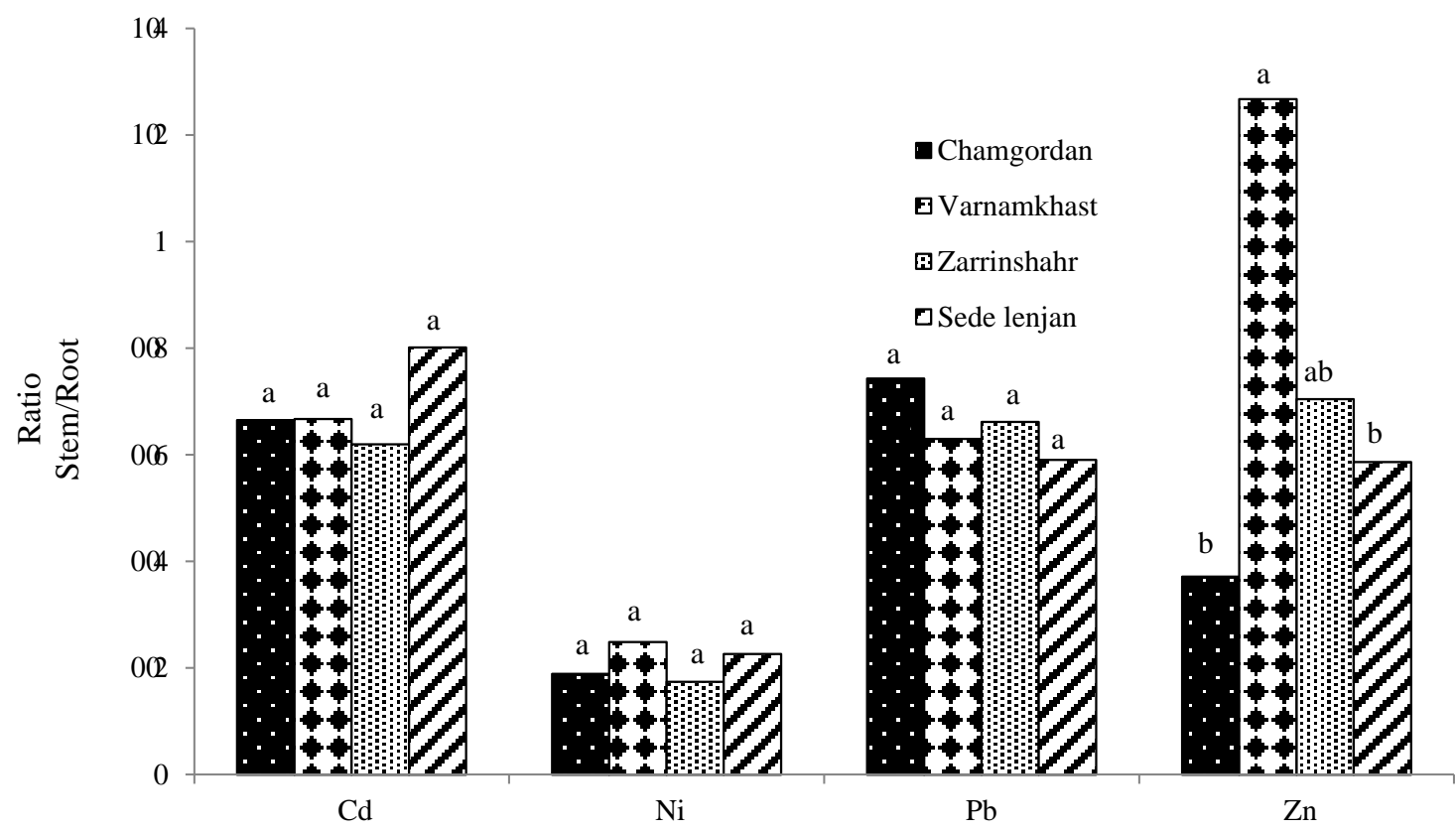

Figure 4. Metals transfer factor from root to stem of rice (same letters indicate no significant difference) 
this indicates that plant accumulates metals (Singh et al. 2011). BAF values of $\mathrm{Pb}, \mathrm{Ni}$ and $\mathrm{Zn}$, were less than 1 in the rice grain. The results indicated that metal bioavailability was low in the study area.

3.5.2 Translocation of metals from roots into the upper parts of the rice plant

The translocation factor (TF) is an indication of the degree of metal translocation from soil to plant. It expresses a plant's capacity to store heavy metals in its upper part. The TF is described as the ratio of metal concentration in the upper part to that in the roots (Boularbah et al. 2006). Figures 3, 4 and 5 show the translocation factors (TF) of different heavy metals from soil to the rice plant. The TF is regarded as one of the key components of human exposure to heavy metals through the food chain (Singh et al. 2011). The TFs of metals from soil to root $\left(\mathrm{TF}_{\text {Soil }}\right)$, root to stem $\left(\mathrm{TF}_{\text {Root }}\right)$ and stem to grain $\left(\mathrm{TF}_{\text {stem }}\right)$ were calculated in the study. The average soil-to-root translocation $\left(\mathrm{TF}_{\text {Soil }}\right)$ were found to be in order of $\mathrm{Cd}(1.52)>\mathrm{Pb}(0.486)>\mathrm{Zn}(0.389)>\mathrm{Ni}$ $(0.201)$. It is illustrated that rice root accumulated high quantities of $\mathrm{Cd}^{+2}$ when grown in non-polluted areas, hence $\mathrm{Cd}^{+2}$ was proved to be more bioavailable to plants than other heavy metals, resulting in a higher biological absorption coefficient for $\mathrm{Cd}$ (Singh et al. 2011). The $\mathrm{TF}_{\text {Root }}$ values were found in the following order: $\mathrm{Zn}(0.732)>\mathrm{Cd}(0.688)>\mathrm{Pb}$ $(0.656)>\mathrm{Ni}(0.209)$.

The root-to-straw translocation values in the study area were less than 1 (except Zn), with no significant difference in TF values among different regions. The translocation values for the straw to grain $\left(\mathrm{TF}_{\text {Straw }}\right)$ in the study area were found in the following order: $\mathrm{Zn}(1.228)>\mathrm{Cd}(0.854)>\mathrm{Pb}(0.456)>$ $\mathrm{Ni}(0.24)$. For most metals (except Zn), the straw-tograin $\mathrm{TF}$ values were less than 1 , with no significant difference in TF values among different regions. It is because most of the heavy metals are often confined in the roots after paddy plant uptake. Also, for all the heavy metals, the TF values at stem were less than the grain, while at the grains, the values come close to the TF at the root. It appears due to atmospheric deposition and the plants' exposure to factory chimneys all over the years.

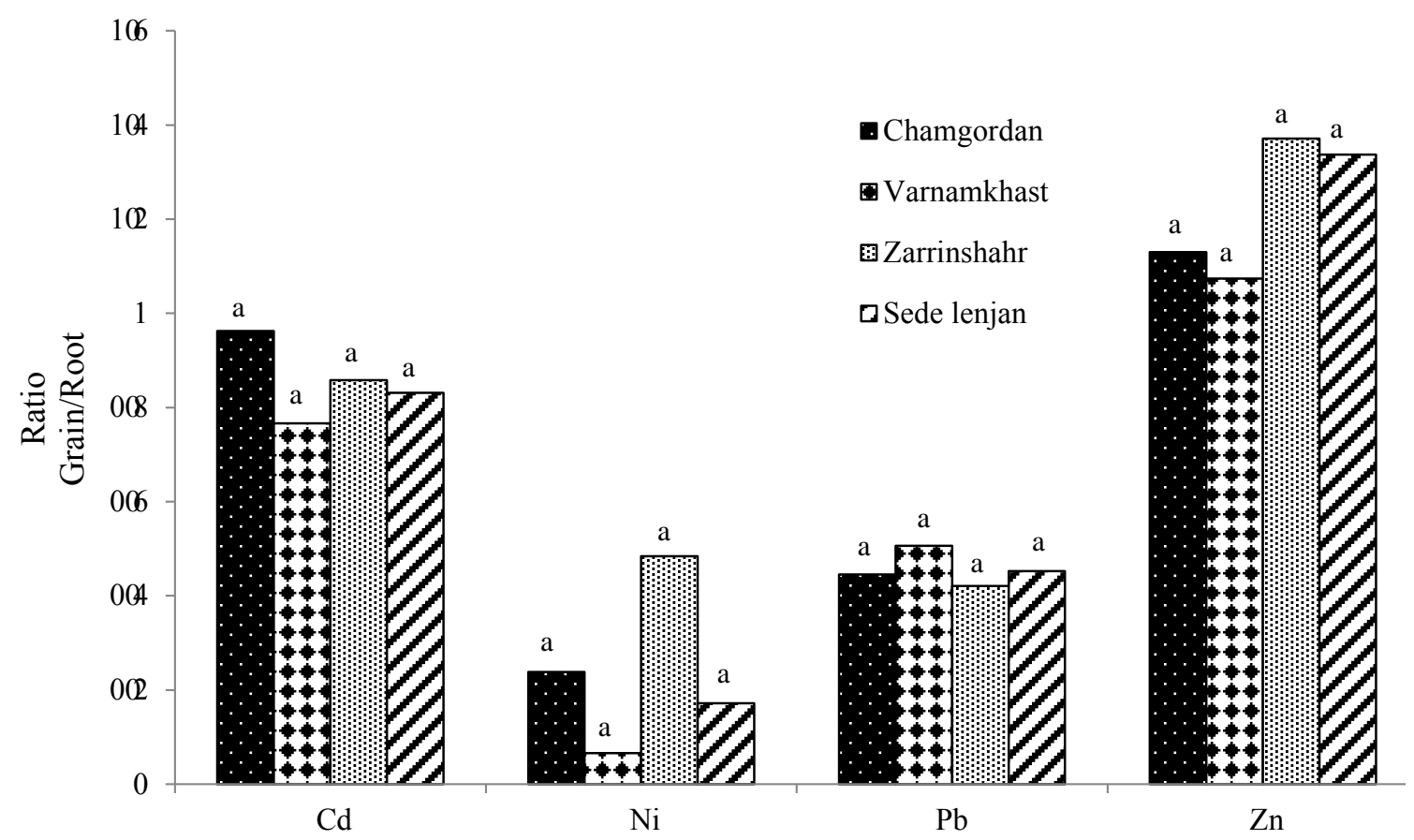

Figure 5. Metal transfer factor from root to grain of rice (same letters indicate no significant difference) 
3.5.3 Coefficients of correlation between metals in the soils and the rice plants

Variability in soil properties and plant growth conditions often lead to not a direct relationship between total metal concentrations in soils and plants (Obrador et al. 2007). However, one of the reasons for the lack of a significant relationship between metal concentrations in soils and plants can be attributed to sources of contamination in the soil. In the present study, the concentrations of $\mathrm{Cd}, \mathrm{Zn}$ and $\mathrm{Ni}$ in soil with their concentrations in the rice plant's roots showed a significant positive correlation (Table 6). The correlations between the stem and seed were positive but not statistically significant. Singh et al. (2010) in a study, obtained a positive correlation between the concentration of $\mathrm{Cd}$ in soil and its concentration in rice, but same correlations were negative for Ni. Also, Hang et al. (2009) found out a significant positive correlation $(r=0.353$, $p<0.05)$ between $\mathrm{Cd}, \mathrm{Zn}$ and $\mathrm{Ni}$ concentrations in soils and rice. In the present study, the concentration of $\mathrm{Pb}$ in the soil did not correlate with the amount absorbed by the rice, which was consistent with the findings of Zhao et al. (2010).

$\mathrm{Pb}$ is taken up by plants to some extent. Plants took up only $0.003-0.005 \%$ of the total soil $\mathrm{Pb}$ (Kalavrouziotis et al. 2012). However, in the present study, relatively high accumulation of $\mathrm{Pb}$ was observed in stems and grains of the plant (Figures 4 and 5). Data revealed that $\mathrm{Pb}$ concentrations in all examined parts of the rice plant were much higher than the preset normal standard -i.e. $(1-5 \mathrm{mg} / \mathrm{kg}$ DM. It was consistent with the results of Nayek et al. (2010). It seems to us that adjacent factory chimneys could be blamed for such high $\mathrm{Pb}$ concentrations.

\section{CONCLUSIONS}

This study determined the accumulation of heavy metals in some paddy soils and rice plants which were collected simultaneously at harvest period. Meanwhile, the farms had been irrigated with contaminated water amid rising public and consumer concerns about the safety and health of local and imported rice in the market. It was found out that contrary to residents' expectations, anthropogenic industrial, municipal and agricultural activities have been changing the famous image of Lenjan aromatic rice for long, exceeding many safety standards in some cases. Based on the data obtained in the study, the agricultural soils, collected from four different locations in Lenjan region, central Iran were severely contaminated by $\mathrm{Cd}$, followed by $\mathrm{Ni}, \mathrm{Pb}$ and $\mathrm{Zn}$. Assessed levels of $\mathrm{Cd}, \mathrm{Pb}, \mathrm{Ni}$ and $\mathrm{Zn}$ were above the standard limits in this area. However, concentrations of metals in the studied water samples were found to be within the permissible limit set by international authorities, except for Ni. High concentrations of $\mathrm{Ni}$ in the Zayandeh Rood river could be attributed to the aggregating discharge of municipal and industrial wastewater. The BAF for $\mathrm{Cd}$ was at maximum compared to other metals among the four locations. Most of the studied heavy metals were found accumulated mostly in the roots of the paddy plant. All of them had concentrations higher than the standard levels. Meanwhile, some plant parts, including the stems and grains contained, relatively high concentrations of $\mathrm{Cd}$ and $\mathrm{Pb}$ in comparison with the standards in all studied locations. They were much higher than the standards of $\mathrm{FAO} / \mathrm{WHO}$, meaning that consumption of such rice could be harmful to consumers (both humans and animals). In some cases, they had far exceeded the critical level. Low correlation discovered between the concentration of $\mathrm{Pb}$ in different parts of the plant and the soil on one, hand, and the relatively high metal contents detected in the rice grains on the other, suggested that aerial deposition was a potential source of metal contamination in rice. In regards to the national food safety criteria, $\mathrm{Pb}$ content in all rice samples exceeded the national MAC. In general, factors such as municipal and industrial wastewater increased the traced metal concentrations. Stricter monitoring of soil, plant, and water quality, together with tougher implementation of governmental regulations are among prerequisites to decline potential health hazards caused by irrigating with metal-polluted river water.

\section{REFERENCES}

ABBAS, S.T. - SARFRAZ, M. - MEHDI, S.M. - HASSAN, G. - UR-REHMAN, O. 2007. Trace elements accumulation in soil and rice plants irrigated with the contaminated water. In Soil \& Tillage Research, vol. 94, pp. 503-509.

AGARVAL, S.K. 2002. Pollution management: water pollution. New Delhi : A. P. H. Publ. 384 pages. 
ALLOWAY, W.H. 1968. Environmental cycling of trace elements. In Advanced Agronomy, vol. 20, pp. 255-265.

AYERS, R.S. - WESTCOTT, D.W. 1985. Water quality for agriculture. Irrigation and Drainage, Paper 29, Rome, Italy : FAO, 97 pages

BAUYCOS, G.J. 1962. Hydrometer methods improved for making particle size of soils. In Agronomy Journal, vol. 56, pp. 464-465.

BI, X. - REN, L. - GONG, M. - HE, Y. - WANG, L. - MA, Z.H. 2010. Transfer of cadmium and lead from soil to mangoes in an uncontaminated area, Hainan Island, China. In Geoderma, vol. 155, pp. 115-120.

BOULARBAH, A. - BOULARBAH, CH. - BITTON, G. ABOUDRAR, W. - OUHAMMOU, A. - MOREL, J.L. 2006. Heavy metal contamination from mining sites in South Morocco: assessment of metal accumulation and toxicity in plants. In Chemosphere, vol. 63, pp. 811-817.

CASADO, M. - ANAWAR, H.M. - GARCIA-SANCHEZ, A. REGINA, I.S. 2008. Cadmium and zinc in polluted mining soils and uptake by plants (El Losar mine, Spain). In International Journal of Environment and Pollution, vol. 33, no. 2-3, pp. 146-159.

CHUNG, B.Y. - SONG, C.H. - PARK, B.J. - CHO, J.Y. 2011. Heavy metals in brown rice (Oryza sativa L.) and soil after long-term irrigation of wastewater discharged from domestic sewage treatment plants. In Pedosphere, vol. 21, no. 5, pp. 621-627.

DOBERMAN, A. - FAIRHURST, T.H. 2000. Rice: Nutrient disorders and nutrient management. Handbook series. International Rice Research Institute, Manila, p. 191. ISBN 981-04-2742-5

FACCHINELLI, A. - SACCHI, E. - MALLEN, L. 2001. Multivariate statistical and GIS-based approach to identify heavy metal sources in soils. In Environmental Pollution, vol. 114, pp. 313-324.

FAKOOR JANATI, S.S. - BEHESHTI, H.R. - FEIZY, J. KHOSHBAKHT FAHIM, N. 2011. Determinations of cadmium, lead, arsenic and mercury in rice from Iran. In International Journal of Industrial Chemistry, vol. 2, no. 4, pp. 196-200.

FAN, Y. - ZHU, T. - LI, M. - HE, J. - HUANG, R. 2017. Heavy metal contamination in soil and brown rice and human health risk assessment near three mining areas in central China. In Journal of Healthcare Engineering, vol. 2017, Article ID 4124302, 9 pages. DOI:10.1155/2017/4124302

FAO and WHO. 1984. Contaminants: joint FAO/WHO food standards program. Codex Alimentarius XVII, First edition, pp. $1-33$.

FU, J. - ZHOU, Q. - LIU, J. - LIU, W. - WANG, TH. - ZHANG, Q. - JIANG, G. 2008. High levels of heavy metals in rice (Oryza sativa L.) from a typical E-waste recycling area in southeast China and its potential risk to human health. In Chemosphere, vol. 71, pp. 1269-1275.

HAI, X. - ZHANG, Y.L. - GENG-MAO, ZH. - JIA-GUE, J. SHI-XUE, Y. - ZHAO-PU, L. 2009. Anthropogenic impact on surface water quality in Taihu Lake Region, China. In Pedosphere, vol. 19, no. 6, pp. 765-778.

HANG, X. - WANG, H. - ZHOU, J. - MA, CH. - DU, CH - CHEN, X. 2009. Risk assessment of potentially toxic element pollution in soils and rice (Oryza sativa) in a typical area of the Yangtze River Delta. In Environmental Pollution, vol. 157, pp. 2542-2549.

Iran Meteorological Organization 2017. Retrieved from http:// www.irimo.ir/far/wd/701-Weather-Forcast-Esfahan.html?id $=17556$

JAHED KHANIKI, GH.R. - ZAZOLI, M.A. 2005. Cadmium and Lead Contents in Rice (Oryza sativa) in the North of
Iran. In International Journal of Agriculture \& Biology, vol. 7 , no. 6, pp. 1026-1029.

JUNG, M.CH. - THORNTON, I. 1997. Environmental contamination and seasonal variation of metals in soils, plants and waters in the paddy fields around a $\mathrm{Pb}-\mathrm{Zn}$ mine in Korea. In Science of the Total Environment, vol. 198, pp. 105-121.

KABATA PENDIAS, A. 2010. Trace elements in soils and plants. Boca Raton, London, New York : CRC Press.

KALAVROUZIOTIS, I.K. - KOUKOULAKIS, P. - KOSTAKIOTI, E. 2012. Assessment of metal transfer factor under irrigation with treated municipal wastewater. In Agricultural Water Management, vol. 103, pp. 114-119.

KHAN, S. - CAO, Q. - ZHENG, Y.M. - HUANG, Y.Z. - ZHU, Y.G. 2008. Health risks of heavy metals in contaminated soils and food crops irrigated with wastewater in Beijing, China. In Environmental Pollution, vol. 152, pp. 686-692.

KHAN, S. - REHMAN, S. - CAO, Q. - JEHAN, N. - SHAH, M.T. 2011. Uptake and translocation of lead and pyrene by ryegrass cultivated in aged spiked soil. In International Journal of Environment and Pollution, vol. 45, no. 1-3, pp. $110-122$.

KIZILOGLU, F.M. - TURAN, M. - SAHIN, U. - KUSLU, Y. - DURSUN, A. 2008. Effects of untreated and treated wastewater irrigation on some chemical properties of cauliflower (Brassica olerecea L. var. botrytis) and red cabbage (Brassica olerecea L. var. rubra) grown on calcareous soil in Turkey. In Agricultural Water Management, vol. 95, pp. 716-724.

LAI, Y. - XU, B. - HE, L. - LIN, M. - CAO, L. - WU, Y. MOU, SH. - HE, SH. 2012. Cadmium uptake by and translocation within Rice (Oryza Sativa L.) seedlings as affected by iron plaque and Fe2o3. In Pakistan Journal of Botany, vol. 44 , no. 5 , pp. $1557-1561$.

LINDSAY, W.L. - NORVELL, W.A. 1978. Development of a DTPA test for zinc, iron, manganese, and copper. In Soil Science Society American Journal, vol. 42, pp. 421-428.

LIU, W.X. - SHEN, L.F. - LIU, J.W. - WANG, Y.W. - LI, S.R. 2007. Uptake of Toxic Heavy Metals by Rice (Oryza sativa L.) Cultivated in the Agricultural Soil near Zhengzhou City, People's Republic of China. In Bulletin of Environmental Contamination Toxicology, vol. 79, no. 2, pp. 209-213.

MAHMOUD, E.K. - GHONEIM, A.M. 2016. Effect of polluted water on soil and plant contamination by heavy metals in El-Mahla El-Kobra, Egypt. In Solid Earth, vol. 7, pp. 703-711.

MANATA, D.S. - ANGELONE, M. 2002. Heavy metals in urban soils. A case study from the city of Palermo. In Science of the Total Environment, vol. 300, no. 1, pp. 229-243.

MONTGOMERY, J.M. 1985. Water treatment, principle and design. New York : John Wiley \& Sons, 696 pages.

MOURA, M.C.S. - MOITA, G.C. - NETO, J.M.M. 2010. Analysis and assessment of heavy metals in urban surface soils of Teresina, Piauí State, Brazil: a study based on multivariate analysis. In Comunicata Scientiae, vol. 1, no. 2, pp. $120-127$.

NAYEK, S. - GUPTA, S. - SAHA, R.N. 2010. Metal accumulation and its effects in relation to biochemical response of vegetables irrigated with metal contaminated water and wastewater. In Journal of Hazardous Materials, vol. 178, pp. 588-595.

OBRADOR, A. - ALVAREZ, J.M. - LOPEZ-VALDIVIA, L.M. - GONZALEZ, D. - NOVILLO, J. - RICO, M.I. 2007. Relationships of soil properties with $\mathrm{Mn}$ and $\mathrm{Zn}$ distribution in acidic soils and their uptake by a barley crop. In Geoderma, vol. 137 , pp. 432-443.

PAIS, I. - JONES, J.B. 1997. The Handbook of Trace Elements. Boca Raton, Florida : St. Lucie Press, 240 pages. 
PARK, B.J. - LEE, J.H. - KIM, W.I. 2011. Influence of soil characteristics and arsenic, cadmium, and lead contamination on their accumulation levels in rice and human health risk through intake of rice grown nearby abandoned mines. In Journal of Korean Society Applied Biology Chemical, vol. 54 , no. 4 , pp. $575-582$.

RABBANI, D. - MOSTAFAII, GH.R. - DEHGHANI, R. - GILASI, H. - HOSEIN ABADI, Z. 2015. Evaluation of heavy metals in Iranian and Non-Iranian rice supplied by shopping centers of Kashan, Iran. In Health Sciences, vol. 2, no. 1, pp. 25-29.

RATTAN, R.K. - DATTA, S.P. - CHHONKAR, P.K. - SURIBABU, K. - SINGH, A.K. 2005. Long-term impact of irrigation with sewage effluents on heavy metal content in soils, crops and groundwater-a case study. In Agriculture, Ecosystems and Environment, vol. 109, pp. 310-322.

RODRIGUEZ MARTIN, J.A. - LOPEZ ARIAS, M. GRAUCORBI, J.M. 2006. Heavy metals contents in agricultural topsoils in the Ebro basin (Spain). Application of the multivariate geostatistical methods to study spatial variations. In Environment Pollution, vol. 144, pp. 1001-1012.

ROWELL, D.L. 1994. Soil Science: Method and Application. Harlow : Longman Group.

SEPA 2005. The limits of pollutants in food. China: State Environmental Protection Administration. GB2762-2005.

SILLANPPA, M. - JANSSON, H. 1992. Status of cadmium, lead, cobalt. FAO Soils Bulletin 65. Rome, Italy.

SIMS, J.T. 1996. Lime requirement method of soil analysis, parts: chemical methods. Madison, Wisconsin. USA.

SINGH, A. - SHARMA, R.K. - AGRAWAL, M. - MARSHALL, F.M. 2010. Health risk assessment of heavy metals via dietary intake of foodstuffs from the wastewater irrigated site of a dry tropical area of India. In Food and Chemical Toxicology, vol. 48, pp. 611-619.

SINGH, J. - UPADHYAY, S.K. - PATHAK, R.K. - GUPTA, V. 2011. Accumulation of heavy metals in soil and paddy crop (Oryza sativa), irrigated with water of Ramgarh Lake, Gorakhpur, UP, India. In Toxicological \& Environmental Chemistry, vol. 93, no. 3, pp. 462-473.

SPOSITO, G. 1989. The chemistry of soils. New York : Oxford University Press, 277 pages.

SPOSITO, G. - LUND, J. - CHANG, A.C. 1982. Trace metal chemistry in arid-zone field soils amended with sewage sludge: I. Fractionation of $\mathrm{Ni}, \mathrm{Cu}, \mathrm{Zn}, \mathrm{Cd}$, and $\mathrm{Pb}$ in solid phases. In Soil Science Society American Journal, vol. 46, pp. 260-264.
TARIQ, S.R. - RASHID, N. 2013. Multivariate analysis of metal levels in paddy soil, rice plants, and rice grains: A case study from Shakargarh. In Pakistan Journal of Chemistry, vol. 2013, Article ID 539251, 10 p. http://dx.doi. org/10.1155/2013/539251

THOMAS, G.W. 1996. Soil pH and soil acidity in methods of soil analysis. In KLUTE, A. (Ed.). Part 3. Chemical methods. Madison, Wisconsin, USA, pp. 475-490.

TIWARI, K.K. - SINGH, N.K. - PATEL, M.P. - TIWARI, M.R. - RAI, U.N. 2011. Metal contamination of soil and translocation in vegetables growing under industrial wastewater irrigated agricultural field of Vadodara, Gujarat, India. In Ecotoxicology and Environmental Safety, vol. 74, pp. 1670-1677.

WANG-DA, CH. - GUO-PING, ZH. - HAI-GEN, Y. - WEI, W. - MIN, X. 2006. Genotypic and environmental variation in cadmium, chromium, arsenic, nickel, and lead concentrations in rice grains. In Journal of Zhejiang University Science B., vol. 7, no. 7, pp. 565-571.

WU, CH. - ZHANG, L. 2010. Heavy metal concentrations and their possible sources in paddy soils of a modern agricultural zone, southeastern China. In Environmental Earth Science, vol. 60 , pp. 45-56.

YANG, P. - MAO, R. - SHAO, H. - GAO, Y. 2009. An investigation on the distribution of eight hazardous heavy metals in the suburban farmland of China. In Journal of Hazardous Materials, vol. 167, pp. 1246-1251.

ZAZOLI, M. - BAZRAFSHAN, E. - HAZRATI, A. - TAVAKKOLI, A. 2006. Determination and estimation of Cadmium intake from Tarom rice. In Journal of Applied Science Environment, vol. 10 , no. 3, pp. 147-150.

ZHAO, K. - LIU, X. - XU, J. - SELIM, H.M. 2010. Heavy metal contaminations in a soil-rice system: Identification of spatial dependence in relation to soil properties of paddy fields. In Journal Hazardous Material, vol. 181, pp. 778787.

ZHEN, H.X. - MEI, ZH.D. - QIAN, H.D. - LONG, C. - LIN, ZH.H. - HUI, W. 2009. Heavy metal transfer from soil to vegetable in southern Jiangsu Province, China. In Pedosphere, vol. 19, no. 3, pp. 305-311.

Received: July 31, 2017 